\title{
Intangible resources of competitive advantage: Analysis of 49 Asian airlines across three business models
}

\author{
James Pearson ${ }^{1,2^{1}}$, David Pitfield ${ }^{1}$, Tim Ryley ${ }^{3}$ \\ ${ }^{1}$ Transport Studies Group, Loughborough University, Loughborough, LE11 3TU, UK \\ ${ }^{2}$ Faculty of Engineering and Computing, Coventry University, Coventry CV1 5FB, UK \\ ${ }^{3}$ Griffith Aviation, School of Natural Sciences, Nathan Campus, Griffith University, Brisbane, Queensland \\ 4111, Australia
}

\begin{abstract}
:
Without sustainable competitive advantage firms have limited economic reasons to exist and will decline. Competitive advantage concerns the factors which provide competitive strength. This paper is based upon the resource-based view which considers firm resources to be heterogeneous and which believes that firms only have a small bundle of core resources irrespective of their overall performance. This research establishes the role of 36 intangible resources for 49 Asian airlines across three business models: network airlines; low-cost subsidiaries from network airlines; and low-cost carriers. It uses the VRIN framework, which examines whether resources are valuable, rare, inimitable, and non-substitutable. Research participants distribute points between their chosen seven resources according to their perceived role in firm performance. Resources which meet all four requirements of VRIN are considered core competences and sources of sustained advantage. Across all 49 Asian airlines, the top-three most important resources of advantage are slots, brand, and product/service reputation. While these core resources are predictable, they have not previously been proven within the context of airlines, let alone geographically and by airline model. Results show that the core bundle of resources vary for each model, which helps to explain the difference in performance across models, and that some resources which were expected to be high-ranking, such as organisational culture and customer focus, were not.
\end{abstract}

Keywords: Competitive advantage, resources, Asia, network airlines, low-cost subsidiaries, low-cost carriers

\section{Introduction}

In its 20-year forecast to 2034, IATA expects that worldwide passenger numbers will reach 7.3 billion, up from 3.3 billion in 2014 (IATA, 2014). IATA forecasts that by 2034 routes to, from, and within Asia-Pacific will carry $42 \%$ of all world traffic, with a mean annual growth rate of $4.9 \%$, the joint-highest worldwide. Asia is increasingly at the forefront of world aviation, with Airbus (2011) suggesting that while Asia's proportion of world revenue passenger kilometres (RPKs) will grow to $34 \%$ by 2031, North America's will reduce from $27 \%$ to $24 \%$ and Europe's from $27 \%$ to $20 \%$.

The dramatic growth in air travel to, from, and within Asia is the consequence of the central role played by air transport in tourism, mobility, and hypermobility, but, fundamentally, the by-products of economic growth, especially price, price elasticity, and income elasticity. Given the considerable number of less economically developed countries within South and Southeast Asia, and that air traffic growth is significant when large

\footnotetext{
${ }^{1}$ Corresponding author. Tel.: +44 7896003258

E-mail address: j.pearson@1boro.ac.uk; ac0611@coventry.ac.uk
} 
segments of population reach middle income (Pilarski, 2007), it is not surprising that Asia is growing so dramatically.

Traffic growth within Asia over the past decade has partially been because of the rise of low-cost carriers (LCCs), which in 2014 represented 25.7\% of seats within Asia - virtually identical to the $25.9 \%$ worldwide (CAPA, 2015). This rises to $57 \%$ for Southeast Asia and $56 \%$ for South Asia (CAPA, 2015). The increased competitiveness within Asia, which will increase further following ASEAN open skies scheduled for 2015, has resulted in often significant challenges for the continent's many network airlines - and these threats are growing (Tan, 2014; Fu and Oum, 2014). Asia's network airlines have responded to LCCs in multiple ways, including - more than any other continent - in the growing use of low-cost subsidiaries, or airlines-within-airlines (see, for example, Pearson and Merkert, 2014).

It is fundamental for network airlines, their low-cost subsidiaries, and LCCs to compete effectively as this will determine their likely success or failure. Indeed, firms should have a competitive strategy that is founded upon and that leverages competitive advantage (Holloway, 2008). This is particularly vital within competitive markets, and firms irrespective of size, location, and industry - often face an overwhelming competitive situation. Yet firms may be less likely to explicitly seek competitive advantage as competition increases from a preoccupation with more pressing matters, particularly survival.

The need for competitive advantage is heightened because it does not persist ceaselessly and so must be renewed. Barney (1991) suggested that in the future competitive advantage will become an even stronger source of a firm's strength, hence the growing need for managers, especially from firms within highly volatile markets, exemplified by the airline industry, to develop tools to effectively analyse the internal and external environments to identify the sources that create competitive advantage. This is because sustainable competitive advantage may depend upon the equilibrium between a firm's internal resources and capabilities, and the changing circumstances of its external environment (Hofer and Schendel, 1978). Thus, and given Low et al (2014) showed that intangible resources are the most important of all resources partly from being less replicable, this paper seeks to identify which intangible resources are more and less important for competitive advantage for Asia's airlines, while examining how resources vary in importance for Asia's network airlines, lowcost subsidiaries, and LCCs. 


\section{Existing literature}

Two schools of thought try to explain the source of competitive advantage for firms: the market-based view of the firm (MBV) and the resource-based view of the firm (RBV).

In terms of the MBV, every firm operates within a multi-layered and far-reaching environment, with the external environment often changeable, complex, and uncertain (Wharton School, 1997). While such changes may not be within the control of the firm's managers, they may impact firm performance, growth, and decision-making ability, hence the imperativeness of thorough analysis of the external environment to formulate and reformulate strategy and to achieve the firm's objectives (Barney, 1997; Wit and Meyer, 1998; Grant, 2008; Henry, 2008). The MBV concerns the external environment within which firms exist, and it concerns factors which may influence competition and pricing, such as market structure and market power; the four competitive forces (threat of new entry, threat of substitutes, bargaining power of buyers, and bargaining power of suppliers) affecting competitive rivalry and market attractiveness; and political, economic, social, technological, environmental, and legal considerations. Under the MBV, all firms are considered effectively homogeneous in terms of possessed resources and capabilities (Gilbert, 2010), with firm heterogeneity unable to be sustained in the longer-term. This is because of the inherent mobility of resources, and firms within the same industry receive broadly similar information hence often virtually identical, or 'us-too', strategies (Porter, 1980). As such, competitive advantage cannot be attained.

Clearly, the changeable external environment within which firms exist will greatly influence a firm's strategy, competitive advantage, and likelihood of survival. Yet many now consider the MBV of the firm to be less significant for competitive advantage than the RBV, despite that this may mean a firm is too inward-looking and unaware of what is happening around it. Irrespective, the MBV and the RBV are both crucial; after all, a firm may not possess the required resources and capabilities to compete in its chosen position and the everchanging external environment may determine what must be done, or changed, internally. Hence 'the need to connect the competitive ends (a firm's position in the marketplace) and means (what elements allow it to attain that position) is not just crucial but essential" (Barney and Hesterly, 2008, p.xvi).

The RBV is premised upon the desired consequence of managerial effort being the attainment of sustainable competitive advantage and, therefore, the achievement of aboveaverage returns vis-à-vis industry and key competitors. This is achieved by the "superior 
organisational resources and capabilities to modify the industry's structure or change the competitive game" (Barney, 1991; Prahalad and Hamel, 1990), thereby effectively utilising internal resources to outperform competition and to create sustainable competitive advantage. But resources and capabilities should also prevent losses.

Above-average firm performance does not materialise from the accumulation of potentially rent-generating resources (Hitt et al, 2014), and it does not simply concern unique bundles of resources. Instead, it necessitates more effectively using the available resources, and it requires management leadership that is creative, imaginative, entrepreneurial, and with a long-term investment in resources (Conner, 1991). Inherent in this is resource selection, with the selection and deployment of resources coexisting with strategic industry factors, particularly supplier power, competitive intensity, and industry and product market structure (Oliver, 1997), which together influence rent-generating potential. Amit and Schoemaker (1993) insist that "the challenge for managers is to identify, develop, protect, and deploy resources and capabilities in a way that provides a firm with a sustainable competitive advantage and thereby superior return on capital."

Greater profitability may be achieved either through maximising resource productivity or from deploying resources in a more profitable manner. Yet resources are not in themselves valuable or productive but rather enable a firm to perform particular activities within specific markets. Indeed, competitive advantage does not materialise from the final product or offered service but from the resources that produced them, although competitive advantage will not be sustainable unless the firm uses its resources "to enable it to produce efficiently and/or effectively a market offering that has value for some market segment or segments" (Hunt and Moran, 1995, p.6). Achieved through organisational capabilities, this indicates that firms must continually deliver customer value, hence the intrinsic role of resources in developing value-creating strategies (Porter, 1980; Barney, 1991). Indeed, the RBV suggests that managers may obtain greater advantage by "combining, developing, and utilising resources to create more valuable results than competitors" (Conner, 1991). As such, resources are merely inputs to the production process and the intermediate link between activities and advantage (Grant, 1991).

Resources are commonly categorised into three sub-groups: tangible assets; intangible assets; and capabilities.

Tangible resources are physical assets, such as property, vehicles, and machinery, that have a fixed long-term capacity and are comparatively easy to measure. However, tangible assets are unlikely to be sources of sustainable competitive advantage because they are easy 
to duplicate and are therefore relatively imitable, substitutable, and mobile. In contrast, intangible resources are deemed the most important strategically (see, for example, Barney, 1991; Carmeli, 2001; Hall, 1992, 1993; Itami and Roehl, 1987; Michalisin et al, 1997). Intangible resources are based upon knowledge or information, for example organisational culture, product reputation, and a firm's brand. The capacities of intangible assets are unlimited, and the value of them may be exploited by renting them (such as licences or patents) or selling them (for example, brands).

A variety of intangible resources have been found to impact firm performance, notably tactic knowledge (Berman et al., 2002); customer relationships (Gouthier and Schmid, 2003); firm reputation and organisational culture (Hall, 1992; Michalisin et al., 1997); product reputation (Hall, 1992); cooperative capabilities (Tyler, 2001); human capital and employee knowhow (Hitt et al., 2001); and information technology (Powell and Dent-Michallef, 1997). Hall (1993) also found that the perception of quality, the ability to manage change, the ability to innovate, and the ability to work effectively within a team all contributed to firm performance.

Whether resources provide sustainable competitive advantage depends upon the type and nature of the resource, the capabilities a firm has, how these have been amassed, and how they are used. Resources provide the potential for competitive advantage but sustainable competitive advantage necessitates that resources must be scarce, unique, non-tradable, inimitable, durable, idiosyncratic, and non-substitutable (Rumelt, 1984; Barney, 1991; Mahoney and Pandian, 1992; Peteraf, 1993; and Amit and Schoemaker, 1993). An effective way to understand the sustainability of competitive advantage is offered by the VRIN framework. This comprises resources that have value, where resources must provide value or counteract threats posed by competitors; are rare, so the resources cannot be obtained and utilised by a number of competitors; imperfectly imitable (or nowadays hard to inmate), so they cannot be duplicated by competitors; and must not have substitutes (or nowadays be hard to substitute), for instance that the resources cannot be easily imitated or commonly used by competitors $^{2}$ (Henkel et al, 2014). Cao et al (2014) found that firms that use resources meeting the full requirements of the VRIN framework are more likely to attain a sustainable competitive advantage. Furthermore, Barney (1991) showed that such resources

\footnotetext{
${ }^{2}$ The requirement of not having substitutes is similar to resources being imperfectly imitable. As such, Barney (1997), in response to criticism from Black and Boal (1994), replaced not having substitutes with organisational process, with the VRIN becoming VRIO. However, this is seldom used in practice.
} 
deemed core competencies and adherence to the framework explains the performance differences among firms. This can be seen within Table 1 .

Table 1: Estimating the level of mean firm performance in an industry

\begin{tabular}{|l|l|l|l|l|l|l|}
\hline \multicolumn{5}{|c|}{ Are the resources: } & & Likely firm performance \\
\hline Valuable? & Rare? & $\begin{array}{l}\text { Hard to } \\
\text { imitate? }\end{array}$ & $\begin{array}{l}\text { Hard to } \\
\text { Substitute? }\end{array}$ & $\begin{array}{l}\text { Exploited } \\
\text { by firm? }\end{array}$ & $\begin{array}{l}\text { Competitive } \\
\text { Implications }\end{array}$ \\
\hline No & No & No & No & No & Competitive disadvantage & Below-average \\
\hline Yes & No & No & No & Yes & Competitive parity & Average \\
\hline Yes & Yes & No & No & Yes & Temporary advantage & Above-average \\
\hline Yes & Yes & Yes & Yes & Yes & Sustained advantage & Consistently above-average \\
\hline
\end{tabular}

Source: Peng (2008).

Carmeli (2001) recognised that, irrespective of a firm's performance, it will have only a small bundle of core resources, often five to seven.

\section{Methodology}

This research determines the core resources for network airlines, their low-cost subsidiaries, and LCCs within Asia. This will not only establish core resources for Asian airlines generally, but also core resources for clusters arranged by type of model.

This paper is structured as follows. This section provides a comprehensive overview of the methodology used, while the results are then presented and discussed in section 4 . Section 5 outlines the concluding remarks.

Despite its importance, defining the 'core resources' of a firm is a complicated task. Hoskisson et al (1999, p.442) suggested that this is "because the RBV emphasises the idiosyncratic nature of a firm's resources and capabilities, empirical testing of the resourcebased theory faces great challenges." Yet the identification of intangible resources is crucial to determine what drives firm advantage and performance, and this is no different for airlines. As such, the ranking of resources is a fundamental requirement and commonplace method (Hall, 1992). However, the ranking of resources has traditionally been limited because of utilising the ordinal ranking system (Robinson, 2008), for it produces a ranking which are insufficiently distinguished. This therefore provides limited information between resources. As such, Carmeli (2001) used the interval rating technique which Collis and Montgomery (1995) determined as "allowing the superiority of resources to be analysed more accurately." It is for this reason that this research into interval resources also utilises the internal rating technique. 
The starting point of this analysis was the collection of data using an Excel file which was sent to participants along with a link to a questionnaire. This formed part of broader research into the competitive advantage and competitive responses of Asian airlines. Senior management in strategy, finance, and business development at 49 Asian airlines across three business models (22 network airlines, 11 low-cost subsidiaries from network airlines, and 16 LCCs) from three sub-regions of Asia (South, Southeast, and Northeast) participated in this research. These airlines can be seen in Table 2. Those who participated were primarily contacted via the professional social networking site LinkedIn, and later asked to participate.

The nature of this research necessitated a large sample of airlines from each of the three airline models in question. It is important to note that 49 airlines represent the overwhelming majority of network airlines, low-cost subsidiaries, and LCCs in the three main sub-regions of Asia, and that the vast majority of the most important are included. The three primary exceptions were Singapore Airlines, China Southern, and Japan Airlines. 
Table 2: List of sampled airlines

\begin{tabular}{|c|c|c|c|}
\hline Country & Network airlines & Low-cost subsidiaries & LCCs \\
\hline \multirow[t]{3}{*}{ India } & Air India & Air India Express & IndiGo \\
\hline & Jet Airways & & SpiceJet \\
\hline & & & Go Air \\
\hline Sri Lanka & SriLankan Airlines & Mihin Lanka & - \\
\hline Myanmar & $\begin{array}{l}\text { Myanmar Airlines } \\
\text { (MAI) }\end{array}$ & - & Golden Myanmar \\
\hline Vietnam & Vietnam Airlines & Jetstar Pacific & VietJet \\
\hline Thailand & Thai Airways & Nok Air & Thai AirAsia \\
\hline Malaysia & Malaysia Airlines & - & Malaysia AirAsia \\
\hline Singapore & SilkAir & Tigerair & - \\
\hline & & Jetstar Asia & \\
\hline Indonesia & Garuda Indonesia & Citilink & Lion Air \\
\hline & & & Indonesia AirAsia \\
\hline Brunei & Royal Brunei & - & - \\
\hline Philippines & Philippine Airlines & - & Cebu Pacific \\
\hline & & & Tigerair Philippines \\
\hline Macau & Air Macau & - & - \\
\hline Hong Kong & Cathay Pacific & & - \\
\hline & Hong Kong Airlines & Hong Kong Express & \\
\hline & Dragonair & & \\
\hline Taiwan & China Airlines & - & - \\
\hline & EVA Air & & \\
\hline China & Air China & - & Spring Airlines \\
\hline & China Eastern & & \\
\hline & Hainan & & \\
\hline South Korea & Korean Air & Air Busan & Jeju Air \\
\hline & & Jin Air & Eastar \\
\hline & & & T'way \\
\hline Japan & All Nippon & Peach & Skymark \\
\hline & & & \\
\hline Totals & 22 & 11 & 16 \\
\hline
\end{tabular}


Participants were given an alphabetically ordered list of 36 intangible resources. These resources were a combination of those generic to all firms (see, for example, Aaker, 1989; Carmeli, 2001; Hall, 1992, 1993; Fernandez et al (2000); Itami and Roehl, 1987; Robinson, 2008) and those specific to airlines. The list of resources is shown within Table 3.

Table 3: Resources used in this research

\begin{tabular}{|l|l|}
\hline Ability to learn & Organisational communication \\
\hline Ability to raise funds & Organisational culture \\
\hline Aircraft leases & Organising \\
\hline Bilateral air service agreements/traffic rights & Product/service reputation \\
\hline Brand & Quality standards/professionalism \\
\hline Business environment & Relationships with employees/suppliers \\
\hline Customer focus & Relationships with local/national governments \\
\hline Databases/information systems & Research and development (R\&D) \\
\hline Decision-making capabilities & Slots \\
\hline Distribution system & Stable leadership \\
\hline Entrepreneurial capabilities & Strategic goals/planning \\
\hline Financial stability & Strategic partners \\
\hline Intellectual property (trademarks, copyrights, patents, etc.) & Supply contracts \\
\hline Knowhow & Teamwork \\
\hline Legal knowledge & Technical experience \\
\hline Managerial competence/experience & Trained/experienced workforce \\
\hline Managing principles/corporate governance & Training programmes \\
\hline Marketing/promotional activities/strategies & Trustworthiness/dependability \\
\hline
\end{tabular}

From these 36 resources, the participants were initially asked to choose up to seven resources that are possessed and valued by their airline and then to distribute 203 points between them based upon the value of each selected resource to their firm's performance. Per Carmeli (2001), the number of points to allocate among resources (203) was calculated by the number of resources (36) minus seven multiplied by seven (the number of resources to be selected). Seven is used because of the interval weighting technique which rates attributes from one to seven. It is this allocation of points between resources that conforms to the interval rating technique as opposed to respondents stating a score of one to seven for each resource per the ordinal rating technique. For example, organisational communication and organisational reputation are two commonplace intangible resources. If it was perceived that reputation was more valuable than communication, it would, when using ordinal ranking technique, receive a score of one and communication two. However, reputation may, when using the interval ranking technique, receive 46 points, while communication may receive 29 points. The relative difference between the two can then be identified. 
The respondents were asked to select and to score the resources per the provided instructions. They had to distribute 203 points among the seven chosen resources based upon their value; 203 for their rareness; 203 for their inimitability; and 203 for their substitutability. While valuable resources required more than zero points, zero points could be allocated for the rarity, inimitability, and substitutability aspects of VRIN. For example, the ability to learn could receive a large number of points by a participant for being a highly valuable resource yet it could receive zero points for not being rare. Thus, a resource could receive a high or low score for value (note that a high score is required if it is to be deemed strategic) and a high, low, or zero score for rareness, inimitability, and substitutability. Those resources that meet all four requirements of VRIN are deemed strategic assets or core competencies because they are sustainable internal sources of competitive advantage.

\section{Results of intangible resources as internal sources of competitive advantage}

The overall rankings of each of the 36 intangible resources as sources of competitive advantage for network airlines, low-cost subsidiaries, and LCCs combined can be seen in Table 4. This is based upon the accumulated scores for each element of VRIN across all three business models. Table 4 therefore represents the rankings of intangible resources for all surveyed 49 airlines across Asia, and the rankings of resources for Asian airlines generally. That the resources in Table 4 (see Total $\overline{\mathrm{x}}$ scores) are ranked by their importance as sources of advantage means that resources which had fewer or even zero points are simply less important in this context. Despite this, it could be that they are still important for an airline in different respects. 
Table 4: Overall rankings of the 36 intangible resources for Asian airlines as sources of competitive advantage

\begin{tabular}{|c|c|c|c|c|c|c|c|c|c|c|c|c|c|c|c|c|c|c|}
\hline \multirow[b]{3}{*}{ Ranking $^{3}$} & \multirow[b]{3}{*}{ Resource } & \multicolumn{17}{|c|}{ INTANGIBLE RESOURCES WHICH ARE... } \\
\hline & & \multicolumn{3}{|c|}{ Valuable } & \multirow[t]{2}{*}{$\bar{x}$} & \multicolumn{3}{|c|}{ Rare } & \multirow[t]{2}{*}{$\bar{x}$} & \multicolumn{3}{|c|}{ Hard to copy } & \multirow[t]{2}{*}{$\bar{x}$} & \multicolumn{3}{|c|}{ Hard to substitute } & \multirow[t]{2}{*}{$\bar{x}$} & \multirow[b]{2}{*}{ Total $\overline{\mathbf{x}}$ scores $^{4}$} \\
\hline & & NA & LCS & LCC & & NA & LCS & LCC & & NA & LCS & LCC & & NA & LCS & LCC & & \\
\hline 1 & Slots & 16.1 & 21.6 & 30.6 & 22.3 & 18.6 & 27.3 & 29.9 & 24.4 & 20.7 & 23.1 & 28.1 & 23.2 & 20.5 & 20.6 & 32.3 & 24.6 & 94.5 \\
\hline 2 & Brand & 21.5 & 14.3 & 21.7 & 20.0 & 19.5 & 15.5 & 24.0 & 20.1 & 32.9 & 22.5 & 24.7 & 27.9 & 24.0 & 22.8 & 22.2 & 23.1 & 91.1 \\
\hline 3 & Product/service reputation & 26.4 & 10.2 & 7.4 & 16.4 & 36.0 & 9.6 & 7.5 & 20.3 & 17.0 & 6.7 & 5.4 & 10.9 & 28.6 & 8.5 & 8.5 & 17.0 & 64.6 \\
\hline 4 & Managerial competence/experience & 12.0 & 14.5 & 17.5 & 14.5 & 17.7 & 19.8 & 19.7 & 18.9 & 9.8 & 16.4 & 20.0 & 15.3 & 9.9 & 19.1 & 17.4 & 14.5 & 63.2 \\
\hline 5 & Strategy and strategic goals/planning & 15.5 & 17.0 & 13.4 & 15.1 & 15.4 & 15.8 & 12.4 & 14.5 & 13.4 & 13.3 & 15.3 & 13.8 & 13.7 & 12.3 & 12.3 & 12.9 & 56.3 \\
\hline 6 & Marketing/promotional activities/strategies & 15.5 & 7.3 & 17.1 & 14.2 & 9.8 & 6.4 & 16.4 & 11.3 & 17.4 & 7.3 & 15.6 & 14.1 & 14.8 & 5.5 & 16.0 & 13.1 & 52.7 \\
\hline 7 & Bilaterals/traffic rights & 10.0 & 11.8 & 14.8 & 10.5 & 12.3 & 17.1 & 14.7 & 14.2 & 12.3 & 18.2 & 11.5 & 11.8 & 8.6 & 11.5 & 9.9 & 9.7 & 46.2 \\
\hline 8 & Ability to raise funds & 12.7 & 7.3 & 8.0 & 9.9 & 7.5 & 4.5 & 7.6 & 6.9 & 6.5 & 4.9 & 8.6 & 7.0 & 8.5 & 5.5 & 9.4 & 8.1 & 31.9 \\
\hline 9 & Relationships with local/national governments & 11.4 & 4.5 & 2.4 & 6.8 & 10.5 & 6.8 & 3.3 & 7.2 & 13.7 & 2.7 & 3.3 & 8.2 & 13.4 & 4.5 & 6.5 & 9.1 & 31.3 \\
\hline 10 & Ability to learn & 9.5 & 7.3 & 7.6 & 8.4 & 8.2 & 1.8 & 4.7 & 5.6 & 16.3 & 1.8 & 5.9 & 10.1 & 8.2 & 4.1 & 4.7 & 6.1 & 30.2 \\
\hline 11 & Trained and experienced workforce & 4.6 & 6.5 & 9.4 & 6.6 & 4.2 & 6.6 & 11.1 & 7.1 & 5.7 & 6.3 & 8.4 & 6.7 & 5.6 & 6.0 & 8.0 & 6.5 & 26.9 \\
\hline 12 & Business environment & 5.2 & 5.3 & 7.1 & 5.9 & 4.6 & 4.3 & 5.7 & 4.9 & 6.8 & 9.3 & 7.6 & 7.9 & 5.1 & 10.5 & 7.8 & 7.2 & 25.9 \\
\hline 13 & Teamwork & 3.0 & 8.5 & 5.3 & 5.0 & 5.1 & 11.5 & 7.7 & 7.4 & 4.8 & 11.5 & 5.9 & 6.5 & 5.5 & 10.9 & 5.1 & 6.5 & 25.4 \\
\hline 14 & Distribution system & 3.1 & 9.6 & 12.3 & 7.7 & 2.2 & 3.6 & 5.8 & 3.8 & 2.0 & 5.5 & 7.1 & 5.0 & 1.9 & 7.6 & 7.1 & 4.9 & 21.4 \\
\hline 15 & Quality standards/professionalism & 12.3 & 3.6 & 0.0 & 6.2 & 9.9 & 2.7 & 0.0 & 5.0 & 4.4 & 1.8 & 0.0 & 2.8 & 14.6 & 4.0 & 0.0 & 7.3 & 21.3 \\
\hline 16 & Financial stability & 1.0 & 11.4 & 5.3 & 4.7 & 0.6 & 13.7 & 5.9 & 5.3 & 0.8 & 11.8 & 9.3 & 5.3 & 0.0 & 8.1 & 8.5 & 4.7 & 20.0 \\
\hline 17 & Decision-making capabilities & 1.8 & 6.0 & 6.0 & 4.2 & 1.6 & 7.7 & 5.0 & 4.1 & 1.1 & 7.6 & 4.5 & 3.9 & 1.1 & 8.5 & 4.8 & 4.0 & 16.2 \\
\hline 18 & Relationships with employees/suppliers, etc. & 3.8 & 5.0 & 3.5 & 4.0 & 3.0 & 4.6 & 3.8 & 3.6 & 4.8 & 5.5 & 3.9 & 4.5 & 3.0 & 4.8 & 3.3 & 3.5 & 15.6 \\
\hline 19 & Trustworthiness/dependability & 4.5 & 7.8 & 0.0 & 3.7 & 6.4 & 4.2 & 0.0 & 3.7 & 2.7 & 3.5 & 0.0 & 2.3 & 5.6 & 4.9 & 0.0 & 3.6 & 13.3 \\
\hline 20 & Organisational culture & 1.2 & 5.6 & 1.5 & 2.3 & 0.8 & 4.0 & 1.0 & 1.6 & 1.9 & 7.5 & 2.4 & 3.8 & 2.5 & 10.0 & 3.2 & 4.4 & 12.1 \\
\hline 21 & Knowhow & 2.8 & 4.9 & 1.9 & 2.9 & 2.8 & 6.5 & 2.7 & 3.6 & 2.0 & 5.3 & 1.7 & 2.5 & 1.9 & 4.5 & 1.8 & 2.5 & 11.5 \\
\hline 22 & Entrepreneurial capabilities & 0.9 & 3.4 & 2.8 & 2.1 & 0.4 & 3.6 & 2.4 & 1.8 & 0.4 & 3.3 & 2.1 & 1.6 & 0.1 & 3.2 & 2.1 & 1.5 & 7.0 \\
\hline 23 & Organisational communication & 0.5 & 4.9 & 0.7 & 1.5 & 0.9 & 2.9 & 0.9 & 1.4 & 1.4 & 4.5 & 1.2 & 1.9 & 1.4 & 4.1 & 1.4 & 2.0 & 6.8 \\
\hline 24 & Customer focus & 0.9 & 0.0 & 1.2 & 0.8 & 0.9 & 0.0 & 2.1 & 1.1 & 0.5 & 0.0 & 1.8 & 0.8 & 0.5 & 0.0 & 1.9 & 0.9 & 3.6 \\
\hline 25 & Strategic partners & 1.4 & 0.0 & 0.0 & 0.6 & 1.8 & 0.0 & 0.0 & 0.8 & 1.4 & 0.0 & 0.0 & 0.6 & 1.8 & 0.0 & 0.0 & 0.8 & 2.8 \\
\hline 26 & Research and development & 0.5 & 0.0 & 0.0 & 0.2 & 1.4 & 0.0 & 0.0 & 0.6 & 0.5 & 0.0 & 0.0 & 0.2 & 1.8 & 0.0 & 0.0 & 0.8 & 1.8 \\
\hline 27 & Legal knowledge & 0.8 & 3.1 & 0.0 & 1.0 & 0.0 & 0.0 & 0.0 & 0.0 & 0.5 & 1.8 & 0.0 & 0.3 & 0.1 & 0.5 & 0.0 & 0.2 & 1.5 \\
\hline 28 & Stable leadership & 1.4 & 0.0 & 0.0 & 0.6 & 0.5 & 0.0 & 0.0 & 0.2 & 0.5 & 0.0 & 0.0 & 0.2 & 0.5 & 0.0 & 0.0 & 0.2 & 1.2 \\
\hline 29 & Aircraft leases & 0.0 & 0.0 & 0.0 & 0.0 & 0.0 & 0.0 & 0.0 & 0.0 & 0.0 & 0.0 & 0.0 & 0.0 & 0.0 & 0.0 & 0.0 & 0.0 & 0.0 \\
\hline 30 & Databases/information systems & 0.0 & 0.0 & 0.0 & 0.0 & 0.0 & 0.0 & 0.0 & 0.0 & 0.0 & 0.0 & 0.0 & 0.0 & 0.0 & 0.0 & 0.0 & 0.0 & 0.0 \\
\hline 31 & Intellectual property & 0.0 & 0.0 & 0.0 & 0.0 & 0.0 & 0.0 & 0.0 & 0.0 & 0.0 & 0.0 & 0.0 & 0.0 & 0.0 & 0.0 & 0.0 & 0.0 & 0.0 \\
\hline 32 & Managing principles/corporate governance & 0.0 & 0.0 & 0.0 & 0.0 & 0.0 & 0.0 & 0.0 & 0.0 & 0.0 & 0.0 & 0.0 & 0.0 & 0.0 & 0.0 & 0.0 & 0.0 & 0.0 \\
\hline 33 & Organising & 0.0 & 0.0 & 0.0 & 0.0 & 0.0 & 0.0 & 0.0 & 0.0 & 0.0 & 0.0 & 0.0 & 0.0 & 0.0 & 0.0 & 0.0 & 0.0 & 0.0 \\
\hline 34 & Supply contracts & 0.0 & 0.0 & 0.0 & 0.0 & 0.0 & 0.0 & 0.0 & 0.0 & 0.0 & 0.0 & 0.0 & 0.0 & 0.0 & 0.0 & 0.0 & 0.0 & 0.0 \\
\hline 35 & Technical expertise & 0.0 & 0.0 & 0.0 & 0.0 & 0.0 & 0.0 & 0.0 & 0.0 & 0.0 & 0.0 & 0.0 & 0.0 & 0.0 & 0.0 & 0.0 & 0.0 & 0.0 \\
\hline 36 & Training programmes & 0.0 & 0.0 & 0.0 & 0.0 & 0.0 & 0.0 & 0.0 & 0.0 & 0.0 & 0.0 & 0.0 & 0.0 & 0.0 & 0.0 & 0.0 & 0.0 & 0.0 \\
\hline & & Total & scores & & 198.1 & & & & 199.4 & & & & 199.1 & & & & 199.7 & \\
\hline
\end{tabular}

NA = network airlines; $\mathrm{LCS}=$ low-cost subsidiaries; $\mathrm{LCC}=$ low-cost carriers

${ }^{3}$ The overall resource ranking is based on all 36 resources and is irrespective of the business model and level of performance. It therefore applies to Asian airlines as a whole.

${ }^{4}$ The higher the average resource total, the more important it is and the more emphasis has been placed upon it as a source of competitive advantage. Note that it may be affected by rounding. 
From Table 4, the top-seven most important, or most emphasised, sources of sustainable competitive advantage for Asian airlines generally are slots (a total mean score 94.5); brand (91.1); product and service reputation (64.6); managerial competence and experience (63.2); strategy and strategic goals and planning (56.3); marketing and promotional activities and strategies (52.7); and bilateral agreements and traffic rights (46.2). While these core resources are obvious and predictable, both from a general business and an airline standpoint, they have not previously been proven within the context of airlines, let alone from a narrower geographic or model perspective. Interestingly, the 36 resources rank similarly in total across all four elements of the VRIN framework (mean total score 199.1; $\sigma=0.69$ ), although it is curious that they score lower in total for value (198.1) than for any other VRIN element, with hard to substitute receiving the highest total marks (199.7). The contribution of these 36 resources to competitive advantage is therefore more attributable to being difficult to copy, with the comparative lack of value of these resources for advantage surprising.

In contrast to the core seven resources, some resources which logically should be important for firms, or which literature has suggested are important, received a resource score of zero or a comparatively low score, which suggests their relative unimportance as a source of advantage for Asian airlines generally. For example, technical expertise and databases of information, the latter potentially used for better-targeted marketing or the greater personalisation of services, at least for network airlines to try to increase yield and loyalty, both had a resource total of zero. Furthermore, stable leadership had a total of just 1.2 points vis-à-vis 94.5 for first-ranked slots, and research and development into new products or adaptions to existing products had 1.8 points and was ranked 26 out of 36 resources vis-à-vis ninth out of 22 by the non-aviation firms across disparate industries surveyed by Carmeli (2001). Despite the obviousness of organisational culture as a source of advantage, which has been much discussed in literature, this research found that it ranked 20 out of 36 for Asian airlines generally with a score of 12.1 , and that is was nearly seven times less emphasised than slots. This result was relatively similar to relationships with customers, suppliers, and otherwise, which was ranked 18 and with a score of 15.6. The greatest difference between this research and Carmeli (2001) is that Carmeli's research found that knowhow was the number-one resource, while this research identified that, for Asian airlines, it ranked 21. That Carmeli surveyed firms across various differing industries, but not airlines, may explain this, likewise the different geographic areas. However, the considerable variation of the importance of knowhow is nonetheless notable. 
Unlike Table 4, Table 5 shows the top-seven core resources for network airlines, low-cost subsidiaries, and LCCs. This is based upon accumulating all four elements of VRIN and all of the airlines surveyed from each model. Table 5 shows that each business model has a reasonably distinct bundle of core resources as the relative superiority of resources varies, the standard deviation of the resources varies, and there are different resources contained within each core bundle.

Table 5: Airline business models and their top-seven resources as sources of competitive advantage

\begin{tabular}{|c|c|c|}
\hline & Mean resource score & SD \\
\hline $\begin{array}{l}\text { NETWORK AIRLINES } \\
\text { Core intangible resources of all } 36 \text { irrespective o. }\end{array}$ & & \\
\hline 1. Product/service reputation & 107.5 & \multirow{7}{*}{23.7} \\
\hline 2. Brand & 97.9 & \\
\hline 3. Slots & 76.4 & \\
\hline 4. Strategy and strategic goals/planning & 58.0 & \\
\hline 5. Marketing/promotional activities/strategies & 57.5 & \\
\hline 6. Managerial competence/experience & 49.5 & \\
\hline 7. Relationships with local/national governments & 49.0 & \\
\hline \multicolumn{3}{|c|}{$\begin{array}{l}\text { LOW-COST SUBSIDIARIES } \\
\text { Core intangible resources of all } 36 \text { irrespective of performance }\end{array}$} \\
\hline 1. Slots & 92.7 & \multirow{7}{*}{17.6} \\
\hline 2. Brand & 75.1 & \\
\hline 3. Managerial competence/experience & 69.8 & \\
\hline 4. Bilaterals/traffic rights & 58.5 & \\
\hline 5. Strategy and strategic goals/planning & 58.5 & \\
\hline 6. Financial stability & 45.0 & \\
\hline 7. Teamwork & 42.5 & \\
\hline \multicolumn{3}{|c|}{$\begin{array}{l}\text { LOW-COST CARRIERS } \\
\text { Core intangible resources of all } 36 \text { irrespective of performance }\end{array}$} \\
\hline 1. Slots & 121.0 & \multirow{7}{*}{29.1} \\
\hline 2. Brand & 92.6 & \\
\hline 3. Managerial competence/experience & 74.6 & \\
\hline 4. Marketing/promotional activities/strategies & 65.1 & \\
\hline 5. Strategy and strategic goals/planning & 53.4 & \\
\hline 6. Bilaterals/traffic rights & 46.5 & \\
\hline 7. Trained/experienced workforce & 36.8 & \\
\hline
\end{tabular}

\subsection{Slots as a source of competitive advantage}

Slots are a fundamental way by which airlines of all models may gain competitive advantage and strength. Indeed, slots received the highest score for value of all 36 resources, including for all three models, although it received higher scores still for being rare, hard to copy, and hard to substitute. The overriding significance of slots confirms Doganis (2006, p.25), who found that "airlines that control slots through grandfather rights will enjoy major competitive advantage." 
It is not at all surprising that slots are important for advantage given that they are - like access to adequate terminal facilities, aircraft stands, airport gates, and aircraft maintenance facilities - ordinarily an inherent 'infrastructural' requirement. Slots are often also a traditional requirement for market access, albeit to varying degrees. The significance of slots for the surveyed Asian airlines is because, like elsewhere, they materialise principally from a shortage of them at major and congested airports given high slot possession by incumbent carriers, so resulting in a significant barrier to entry and potentially a monopolistic and anticompetitive situation ( $\mathrm{Fu}$ et al, 2011; Narangajavana et al., 2014). While slots are typically still available for other airlines, they are often at suboptimal times and will likely present a competitive disadvantage, of some degree, to the acquirer. This further strengthens the advantage of an airline with a considerable slot portfolio.

The emphasis by Asian airlines on slots may also be because of the shortage of alternative airports serving metropolitan areas within the continent, which confirms Halpern and Graham (2013) and Duval (2014) who showed that a severe shortage of attractive slots often exists at major airports in Asia. The presence of alternative airports was how a number of European and North American LCCs initially circumvented slot possession by incumbent airlines, together with operational, cost, and at times other financial advantages. This thus fuelled their growth and contributed towards their low-cost strategic positioning. The lack of alternative airports within Asia places a disproportionate degree of importance on slots, which is likely to increase if airport infrastructure is not expanded adequately given the IATA's considerable forecast traffic growth. The disproportionate importance on slots confirms Clayton (2010) and Hutchinson (2013) who found that passenger demand in Asia has often not been met with sufficient investment, hence continuing slot constraints and flight delays.

The possession of slots as a source of advantage is somewhat 'artificial' because it is derived not from internal ability or development - for example, as with a strong brand or quality, reputation, and culture - but from market dominance and market power. As such, even very unsuccessfully performing airlines, financially speaking, might be dominant in terms of slots. However, the possession of slots should lead to other sources of advantage as large-scale presence by airlines at highly trafficked airports may also achieve greater efficiency and a stronger negotiating position from a concentration of services (Havel, 2009). This may therefore further strengthen the overall advantage derived from the mere possession of slots. 
Table 6 shows those network airlines, low-cost subsidiaries, and LCCs which ranked slots as their overall number-one resource in the achievement of competitive advantage, with their score for slots showing the relative superiority of this resource across the 17 airlines. These 17 airlines represented $33 \%$ of all sampled airlines, meaning that a third of Asian airlines consider slots more important than any other intangible resource in achieving advantage. For all 17 airlines, slots were an average $24.2 \%$ more emphasised than the second-ranked resource. While a function of the sample size for each model, $54.5 \%$ of low-cost subsidiaries found slots to be their top resource in comparison to $41.2 \%$ for LCCs and $18.2 \%$ for network airlines. However, it is clear that all 17 airlines are primarily based at busy and congested airports, with mean passenger traffic of 49.3 million in 2013.

It is noteworthy that four airlines across each of the three business models whose primary airport is Jakarta found slots there to be their most important source of advantage. These four airlines emphasised slots $56.2 \%$ more than their second-ranked resource, against $24.2 \%$ for the 17 airlines. That Jakarta featured so heavily confirms Citrinot (2014), who showed that Jakarta/Soekarno-Hatta was designed for 22 million passengers per annum yet is now handling 60 million. To help remedy the highly congested situation, Jakarta's old airport, Halim, was reopened in 2014 for scheduled jet operations to begin to reduce the pressure on Seokarno-Hatta while facilitating further growth (Hashim, 2014). Furthermore, three airlines whose primary airport is Manila/Ninoy Aquino found slots to be their most important. This finding is corresponds to Port Calls Asia (2014), who indicated that Manila's considerable congestion has had many negative implications, including an extra $\$ 156$ million in fuel consumption. A third runway at Manila was announced in December 2014 by the Philippine President (Manila Bulletin, 2014). 
Table 6: Airlines which ranked slots as their number-one resource for competitive advantage

\begin{tabular}{|l|l|l|l|l|}
\hline & $\begin{array}{l}\text { The primary airport } \\
\text { by total seats }\end{array}$ & $\begin{array}{l}\text { Airport passenger } \\
\text { traffic in 2013 }\end{array}$ & $\begin{array}{l}\text { Airline score } \\
\text { for slots }\end{array}$ & $\begin{array}{l}\text { Percentage of slots from } \\
\text { second-ranked resource }\end{array}$ \\
\hline NETWORK AIRLINES & & & & \\
\hline Garuda Indonesia & Jakarta & $59.7 \mathrm{~m}$ & 212 & 26.3 \\
\hline Philippine Airlines & Manila & $32.9 \mathrm{~m}$ & 178 & 40.2 \\
\hline Air India & Delhi & $36.7 \mathrm{~m}$ & 164 & 11.6 \\
\hline Air China & Beijing & $83.7 \mathrm{~m}$ & 154 & 2.7 \\
\hline & & & & \\
LOW-COST & & & & \\
SUBSIDIARIES & & $59.7 \mathrm{~m}$ & 193 & 66.4 \\
\hline Citilink & & $53.7 \mathrm{~m}$ & 178 & 19.5 \\
\hline Jetstar Asia & Jakarta & $53.7 \mathrm{~m}$ & 177 & 22.1 \\
\hline Tigerair & Singapore & $59.9 \mathrm{~m}$ & 170 & 3.0 \\
\hline Hong Kong Express & Singapore & $19.0 \mathrm{~m}$ & 162 & 4.5 \\
\hline Jetstar Pacific & Hong Kong & $20.1 \mathrm{~m}$ & 159 & 13.6 \\
\hline Jin Air & Ho Chi Min City & & & \\
\hline & Jeju & & 280 & 110.5 \\
\hline LOW-COST CARRIERS & & $59.7 \mathrm{~m}$ & 240 & 29.0 \\
\hline Indonesia AirAsia & Jakarta & 193 & 21.4 \\
\hline AirAsia Malaysia & Kuala Lumpur & $47.5 \mathrm{~m}$ & 185 & 1.9 \\
\hline Lion Air & Jakarta & $59.7 \mathrm{~m}$ & 177 & 22.1 \\
\hline Spring Airlines & Shanghai/Pudong & $47.2 \mathrm{~m}$ & 157 & 1.3 \\
\hline Tigerair Philippines & Manila & $32.9 \mathrm{~m}$ & 138 & 14.5 \\
\hline VietJet & Ho Chi Minh City & $20.0 \mathrm{~m}$ & $\mathbf{1 8 3}$ & $\mathbf{2 4 . 2}$ \\
\hline Cebu Pacific & Manila & $32.9 \mathrm{~m}$ & \\
\hline Mean results & & $\mathbf{4 9 . 3 m}$ & & \\
\hline
\end{tabular}

Despite the predictability of the importance of slots, it is surprising that they are the most significant source of sustained advantage across Asian airlines. However, this importance varies by business model, with LCCs finding slots on average $28.4 \%$ more important ${ }^{8}$ (mean score 121.0) than both low-cost subsidiaries (92.7) and network airlines (76.4). Given slot entrenchment is often considered to be the preserve of well-established airlines, which are normally network airlines, this result was not expected. Indeed, LCCs did not commence within Asia until 2001 (BBC, 2010) and low-cost subsidiaries from 2003 (CNN, 2003), and already they deem slots to be a greater source of advantage than network airlines. This is perhaps because it is LCCs and economic growth which have over the past ten years led many Asian airports to become very congested. Thus, LCCs, and low-cost subsidiaries to a

\footnotetext{
${ }^{5}$ Its main airport by number of seats offered by each airline in the week commencing $22^{\text {nd }}$ September 2014, according to the airport profiles section of CAPA.

${ }^{6}$ Based upon passenger numbers in 2013 within the airport profiles section of CAPA.

${ }^{7}$ Shanghai/Pudong has just $6.4 \%$ fewer seats than another very busy airport serving the Shanghai metropolitan area, Shanghai/Hongqiao, and Spring Airlines has significant bases at both facilities. Including both airports, passenger traffic at Spring Airlines' primary airports increases to $82.8 \mathrm{~m}$.

${ }^{8}$ Based upon accumulating valuable, rare, hard to copy, and hard to substitute for each business model.
} 
lesser degree, have diluted the dominance held by network airlines as a percentage of an airport's total, and they realise that newcomers will find it harder still to acquire them. Indeed, in the week starting $5^{\text {th }}$ January 2015 LCCs now have over $30 \%$ of seats at a host of major Asian airports, including Kuala Lumpur (51.3\%); Jakarta (48.7\%); Mumbai (45.7\%); Delhi (44.5\%); Manila (42.3\%); Osaka/Kansai (35.5\%); and Singapore (30\%) (CAPA, 2015). The simplified value propositions and perceived lower quality of LCCs, as reflected in their core seven resources, suggests that it perhaps should not be quite as surprising as it may be.

\subsection{Brands as a source of competitive advantage}

At just $3.7 \%$ less emphasised than slots, for Asian airlines brand as a source of competitive advantage is almost as important. This is despite the value of brands being lower than rare, hard to substitute and, in particular, being hard to copy. This research found that, of the 49 surveyed airlines, 40 airlines (82\%) ranked brand within their core top-seven resources. For these 40, brand featured in the core resource bundle for 18 of 22 network airlines (81.8\%), seven of 11 LCS (64\%), and 13 of 16 LCCs (81\%). Given the surveyed airlines are overwhelmingly commercial enterprises, the significance of brands for them should come as no surprise. This is because Choe and Zhao (2013) found that brands are considered a vital way by which firms achieve differentiation and, in turn, achieve competitive advantage and profitability. There is also a clear relationship between brand equity and brand preference and the purchase intention of customers (Chen and Chang, 2008). Together with conveying the extent of quality, credibility, and experience, brands add value to a product and thereby assists in achieving a price premium. This research confirms previous research and managerial practice, albeit in different industries, which typically contend that brand equity constitutes one of a firm's most valuable resources (Vomberg et al, 2014).

Of the 40 airlines which ranked brand within their core resource bundle, six airlines ranked brand as their number-one resource. These can be seen in Table 7. That only six airlines ranked it such yet brand achieved almost the top overall score for a resource indicates that many airlines placed much emphasis on it, and typically within their top-three resources. For example, AirAsia Malaysia and Cathay Pacific, both with well-managed and internationally known brands, ranked their brands as their second most important source of advantage. In contrast, of all surveyed airlines ten (20.0\%) didn't rank brand within their core resources. These are: Thai Airways; China Eastern; EVA Air; Hainan Airlines; Jetstar Asia; Tigerair; Lion; Golden Myanmar; VietJet; and Tigerair Philippines. These airlines 
deem other resources to be more important than branding in the attainment of competitive advantage.

Table 7: Airlines which ranked brand as the number-one resource for competitive advantage

\begin{tabular}{|l|l|l|}
\hline & Score for brand & Percentage of brand from second-ranked resource \\
\hline NETWORK AIRLINES & & \\
\hline All Nippon & 190 & $37.7 \%$ \\
\hline Korean Airlines & 170 & $14.9 \%$ \\
\hline Air China & 154 & $2.7 \%$ \\
\hline Hong Kong Airlines & 185 & $1.1 \%$ \\
\hline & & \\
LOW-COST SUBSIDIARIES & & \\
\hline None & & \\
\hline & & \\
LOW-COST CARRIERS & & $5.8 \%$ \\
\hline Jeju Airlines & 163 & $1.1 \%$ \\
\hline Spring Airlines & 185 & $\mathbf{1 1 . 0 \%}$ \\
\hline Mean results & $\mathbf{1 7 5}$ & \\
\hline
\end{tabular}

Of the six airlines in Table 7, all are from Northeast Asia, where there is far less LCC competition than South and Southeast Asia: while LCCs had 11.5\% of all seats in Northeast Asia in 2014, they had 56\% in South Asia and 57\% in Southeast Asia (CAPA, 2015). The presence of Northeast Asian airlines corresponds with the Brand Directory (2014) finding that, for the top-20 airline brands in 2013 by value, seven of the eight listed Asian airlines were from Northeast Asia. Given the lack of international exposure by, and recognition of, the two LCCs in Table 7, at least in the West, the emphasis on brand is presumably based upon what is crucial: branding in their own served and core markets.

The very strong ranking of brands is somewhat surprising for airlines because of the stress placed upon the growth of commoditisation of the airline product in economy class and short-haul markets (see, for example, Elian and Cook, 2013 and Kay et al, 2012). However, the reverse may be more logical: the greater the sameness of the economy product across airlines, airline models, and geographies, the greater the need for stronger branding to distinguish between airlines. Indeed, despite the many possible consequences arising from growing commoditisation, Shaw $(2007$, p.263) insists that "airline brands can bring airlines very worthwhile advantages, and make a real contribution to the achievement of satisfactory profits." 


\subsection{Product and service reputation as a source of competitive advantage}

Given the airline industry is a service industry, it is logical and expected that reputation derived from service or product would be a crucial resource in the attainment and sustainment of competitive advantage. This research confirmed this widely held belief, for reputation achieved the third-highest resource total across all Asian airlines of 64.5. Surprisingly, the value of reputation is the second-lowest scoring for all the VRIN elements, and reputation is disproportionately influenced by the much lower scores from both LCCs and low-cost subsidiaries.

Despite the highly significant score of reputation across Asian airlines, reputation was nearly half as important as slots and brand. However, the ranking of reputation, vis-à-vis all 36 analysed resources, confirms literature as to the role of reputation for competitive advantage across firms and industries, including in the context of the airline industry (Barrett, 2009). That branding was found to be so highly important partly further explains why reputation was also so important, for a brand builds reputation. It is thus expected that the two resources coexist. Through its lifecycle model, Board and Vehn (2014) established that reputation is also intricately linked with quality, for firms invest into their quality and thereby their reputation. However, this research found that quality standards and professionalism for Asian airlines, while not necessarily entirely related to quality of product and service, was ranked 15 out of 36 resources, with a mean resource total of 21.3, or two-thirds less important than reputation, with network airlines ranking it much higher than low-cost subsidiaries and LCCs. Competitive advantage from service or product reputation may also have incidental advantages, especially in terms of higher price-equity, lower cost of capital, and stronger market value (Eccles et al, 2007).

From Table 5, it is clear that network airlines across Asia placed a significantly greater emphasis on product and service reputation as a source of advantage than both LCCs and LCS. Indeed, network airlines ranked it as their number-one resource, with an average resource score of 107.5. This is $9.8 \%$ more important than their second-ranked slots, and more than double as important than the seventh-ranked relationships with national and local governments, which ranked seventh in their core resource bundle. Of all 22 network airlines, $14(63.6 \%)$ ranked product and service reputation within their core bundle, with five - Cathay Pacific, All Nippon, Royal Brunei, EVA Air, and SriLankan - ranking it as their number-one source of advantage. Eight network airlines did not rank reputation within their top-seven 
resources: Malaysia Airlines; Thai Airways; Hong Kong Airlines (but brand was numberone); China Airlines; China Eastern; SilkAir; Air Macau; and Hainan Airlines.

The significance of reputation for network airlines is predictable because of their strategic positions, based to varying degrees on differentiation, and because of their complex and expensive products and value propositions which they have developed over many years. The cost of maintaining relative service quality and reputation is therefore high, although Pearson and Merkert (2014) found that a limited relationship exists between airline service levels and profitability. While reputation scored considerably lower for being hard to copy than for all other elements of the VRIN framework, it would be worrying if network airlines did not place such importance on reputation as it would call into question their entire existence. It may be assumed that the network airlines themselves perceive reputation to be of such significance for advantage given their investment in service attributes, which constitute sunk costs, and the emphasis, to varying degrees, on superior quality to lower-cost competition, but this was not really found to be the case. Indeed, it was found that a Spearman's rank correlation of 0.67 ( $p$-value 0.0041 ) exists between the individual scores given by airlines ${ }^{9}$ for product and service reputation and the award, out of five stars, given to each airline after comprehensive analysis by SkyTrax ${ }^{10}$.

Just as the findings concerning network airlines are not surprising, it is also predictable that product and service reputation for both low-cost subsidiaries and LCCs would be considerably less important as a source of advantage. This is because their core customers seek good enough products or services at low prices, hence simplified and straightforward products and value propositions. Thus, it is reasonable that they should place less emphasis upon reputation as a means of achieving and sustaining advantage. Table 6 shows that product and service reputation did not feature in the core bundle of resources for both Asian low-cost subsidiaries and LCCs. In contrast to network airlines, such reputation was twothirds lower for low-cost subsidiaries (a score of 35 against 107.5) and three-quarters less important for LCCs (28.8). Interestingly, while reputation did not appear within the topseven resources for low-cost subsidiaries and LCCs, branding and, for LCCs, marketing and promotional activities and strategies did. This indicates the areas on which low-cost subsidiaries and LCCs deem worthy of attention and investment, although they are somewhat

\footnotetext{
${ }^{9}$ This is based upon 16 of the 21 airlines which ranked product and service reputation within their top-seven resources, and then based upon the availability of a starred ranking for the airlines by SkyTrax.

10 SkyTrax's star system is based upon analysis of more than 800 different items across an airline's front-line product and staff service standards, and applied to the airport and cabin service environments.
} 
interconnected. That LCS collectively emphasised product and service reputation to such a lower degree than network airlines provides a different view to a finding of Graf (2005), who identified that a main negative implication of LCS is that their products and branding is insufficiently differentiated from the parent network airlines.

Of all 11 sampled low-cost subsidiaries, only three (27.3\%) - Air Busan, Jin, and Nok ranked reputation within their top-seven resources, with Air Busan ranking it number-one. Interestingly, Air Busan and Jin Air are from service-orientated South Korea. Of all 16 LCCs, only four ranked reputation within their core bundle, with T'way - also from South Korea - and Malindo ranking it number-one. Given that Malindo is more of a hybrid operator with more comprehensive key product features than AirAsia Malaysia and perceived superior value to Malaysia Airlines, it is not surprising that it ranked reputation so highly, with a $23.1 \%$ greater emphasis than AirAsia (a score of 160 against 130).

\section{Conclusion}

This paper establishes for the first time the relative importance of an array of intangible resources to Asian airlines while crucially showing how this importance varies by airline model. This paper therefore enables a generalised understanding of the role of intangible resources for competitive advantage.

With a forecast 3.1 billion people likely to fly to, from, and within Asia by 2034, and how a mature Europe and North America will represent a lower proportion of world traffic, it is clear that Asia is increasingly representing the new order of world aviation. And with a significant LCC penetration in 2014 of $25.7 \%$, up from $1.1 \%$ in 2001, Asia is becoming increasingly competitive and this will continue.

Every firm has a core bundle of resources which, according to the RBV, accounts for their competitive advantage from an internal perspective. Of the core seven resources for the 49 Asian airlines, the top three resources for competitive advantage were found to be slots, brand, and product and service reputation. While these resources are predictable, they have not previously been proven for airlines, let alone for those within Asia.

That slots was the number-one resource in the achievement of advantage is not particularly surprising given a lack of alternative airports and the high degree of congestion at major airports across Asia. However, it was more surprising that LCCs found slots to be more important, although this can represent a significant barrier to entry to newcomers or smaller airlines wishing to expand. Interestingly, the importance of slots is despite this resource being somewhat 'artificial' because it is derived not from internal ability or 
development, which is perhaps supported by slots possessing a lower score for value than for the other elements of VRIN. This suggests that the primarily intangible resource for Asian airlines is based not on the value that it offers but that they are rare and cannot be substituted except through normal trading.

It was found that a very high degree of importance was placed by Asian airlines generally, but especially network airlines and LCCs, on brands as a source of competitive advantage. Across Asia, it is airlines from Northeast Asia which placed particular emphasis upon brands for advantage, with this sub-region having a considerably lower LCC penetration while airlines from this sub-region often possess higher unit revenues. The lower importance of brands for advantage for low-cost subsidiaries is notable but understandable because of their generally lower public awareness vis-à-vis major LCCs. As brands and product and service reputation are closely related, the importance of reputation for Asian airlines generally was anticipated given the service industry within which airlines operate. As expected, it was shown that Asian network airlines place a considerably higher degree of importance on reputation than both low-cost subsidiaries and LCCs.

Unexpectedly, all 36 resources across all Asian airlines scored less overall for value than for being rare, hard to copy, and hard to substitute. This suggests that, for all resources, intangible resources provide less value or may be less effective in counteracting the threats from competitors. Instead, the resources on an overall basis received the highest score for being hard to substitute, which suggests that they cannot be easily imitated or commonly used by competitors. Given the idiosyncratic nature of many of the resources, and the required time, knowledge, and experience to develop them, this is not particularly surprising. The difficulty of resource substitution is especially acute for slots, brand, product and service reputation, relationships with government, business environment, and quality standards and professionalism. Somewhat reassuringly, strategy and strategic goals and planning was the most valuable of the core seven resources.

Asian network airlines, low-cost subsidiaries, and LCCs each have reasonably distinct core resource bundles which account for their competitive advantage, both in terms of the difference in importance of the resources which are shared and the resources which only one model included as being core. While Asian network airlines ranked product and service reputation as their most important resource for competitive advantage, low-cost subsidiaries and LCCs both ranked slots as their first resource. Indeed, various resources are disproportionately affected by the inclusion of low-cost subsidiaries and particularly LCCs, 
but especially product and service reputation, relationships with governments, and quality standards and professionalism

Crucially, all three models found managerial competence and experience to be within their core bundle of resources for advantage, with LCCs finding this resource to be more important than the other two models. This suggests that low-cost subsidiaries and network airlines should place a greater emphasis upon managerial competence and experience. Overall, it is clear that the sources of competitive advantage, whatever they are, must be strengthened and renewed as appropriate, especially given the increasing competitiveness within Asia.

\section{References}

Aakar, D. A. (1989), Managing Assets and Skills: The Key to a Sustainable Competitive Advantage, California Management Review, volume 31, pp.91-106.

Airbus (2011), Global Market Forecast: Navigating The Future, available at http://www.airbus.com/company/market/forecast/?eID=dam_frontend_push\&docID= $\underline{25773}$ - accessed $22^{\text {nd }}$ January, 2015.

Amit, R. and Shoemaker, P. J. (1993), Strategic Assets and Organisational Rent, Strategic Management Journal, volume 14, pp.33-46.

Barney, J. B. (1991), Firm Resources and Sustained Competitive Advantage, Journal of Management, volume 17, pp. 99-120.

Barney, J. B. (1997), Gaining and Sustaining Competitive Advantage, Addison-Wesley, Reading, USA.

Barney, J. and Hesterly, W. (2008), Strategic Management and Competitive Advantage: Concepts and Cases, second edition, Prentice Hall, USA.

Barratt, S. (2009), Deregulation and the Airline Business in Europe, Routledge, Abingdon.

BBC (2010), How Air Asia Founder Tony Fernandes' Dream Came True, available at http://www.bbc.co.uk/news/business-11647205 - accessed 22nd January, 2015

Berman, S. L., Down, J., and Hill, C. (2002), Tacit Knowledge as a Source of Competitive Advantage in the National Basketball Association, Academy of Management Journal, volume 45, pp13-31.

Black, J. A. and Baol K. B. (1994), Strategic Resources: Traits, Configurations and Paths to Sustainable Competitive Advantage, Strategic Management Journal, volume 15, pp.131-148.

Board, S. and Vehn, M. M. (2014), A Reputational Theory of Firm Dynamics, available at http://www.econ.ucla.edu/mtv/self-esteem.pdf - accessed 22nd January, 2015. 
Brand Directory (2014), Top-20 Airline Brands, available at http://brandirectory.com/league tables/table/top-20-airline-brands-2013 - accessed 22nd January, 2015

Cao. D., Berkeley, N. and Finlay, D. (2014), Measuring sustained competitive advantage from resource-based view: survey of Chinese clothing industry, Journal of Sustainable Development, volume 7, issue 2.

CAPA (2015), Aviation Data: Low Cost Carriers (subscription), available at http://centreforaviation.com/profiles/hot-issues/low-cost-carriers-lccs\#lcc - accessed $22^{\text {nd }}$ January, 2015

Carmeli, A. (2001), High and Low Performance Firms: Do They Have Different Profiles of Perceived Core Intangible Resources and Business Environments?, Technovation, volume 21, pp.661-671.

Chen, C-F and Chang, Y-Y (2008), Airline Brand Equity, Brand Preference, and Purchase Intentions-The Moderating Effects of Switching Costs, Journal of Air Transport Management, volume 14, p.40-42, doi:10.1016/j.jairtraman.2007.11.003.

Choe, P., and Zhao, Y. (2013), The Influence of Airline Brand on Purchase Intention of Air Tickets in China, Industrial Engineering and Management Systems, volume 12, pp.143-150.

Citrinot (2014), Coping Urgently With Congestion at Jakarta Soekarno Hatta International Airport, available at: http://www.traveldailynews.asia/news/article/55364/copingurgently-with-congestion-at - accessed 8th June 2015.

Clayton, E. (2010), Airport Infrastructure in Asia: Coping with the Demand Surge, available at http://www.pwc.com/en_GX/gx/capital-projects-infrastructure/pdf/pwc-airportinfrastructure-in-asia.pdf - accessed 23rd January, 2015.

CNN (2013), Tiger Air to Start Asian Cat Fight, available at http://edition.cnn.com/2003/WORLD/asiapcf/southeast/12/09/biz.trav.tiger.air.reut/ accessed $22^{\text {nd }}$ January, 2015.

Collis, D. J. and Montgomery C. A. (1998), Creating Corporate Advantage, Harvard Business Review, volume 76, pp.70-83.

Conner, Y-F. (1991), A Historical Comparison of Resource-Based Theory and Five Schools of Thought within Industrial Organisational Economics: Do We Have a New Theory of the Firm?, Journal of Management, volume, pp.121-154.

Doganis, R. (2006), The Airline Business, second edition, Routledge, Abingdon.

Duvall, T. D. (2014), Air Transport in Asia-Pacific, Ashgate, Farnham.

Elian, J. and Cook, G. N. (2013), Spirit Airlines: Achieving a Competitive Advantage Through Ultra-Low Costs, Journal of Aviation and Aerospace Education and Research, volume 23, pp.23-34. 
Eccles, R. G., Newquist, S. C., and Schatz, R. (2007), Reputation and Its Risks, Harvard Business Review, February edition.

Fernandez, E., Montes, J. M., Vazquez, C. J. (2000), Typology and Strategic Analysis of Intangible Resources: A Resource-Based Approach, Technovation, volume 20, pp.8192.

Fu, X., Homsombat, W., and Oum, T. (2011), Airport-airline vertical relationships, their effects and regulatory policy implications, Journal of Air Transport Management, volume 17, pp.347-353, doi:10.1016/j.jairtraman.2011.02.004.

Fu, X. and Oum, T. (2014), Air Transport Liberalization and its Effects on Airline Competition and Traffic Growth: an overview, in Peoples, J. (ed), Advances in Airline Economics, Emerald, pp.11-44.

Gouthier, M. and Schmid, S. (2003), Customers and Customer Relationships in Service Firms: The Perspective of the Resource-Based View, Marketing Theory, volume 3, pp.119-143.

Gilbert, M. (2010), Strategy Making in a Crisis: From Analysis to Imagination, Edward Elgar, Cheltenham.

Graf, L. (2005), Incompatibilities of the low-cost and network carrier business models within the same airline grouping, Journal of Air Transport Management, volume 11, issue 5, pp.313326.

Grant, F. B. (1991), A Resource-Based Theory of Competitive Advantage: Implications for Strategy Formulation, California Management Review, volume 33, pp. 114-135.

Grant, R.M. (2008), Contemporary Strategy Analysis, Blackwell, Oxford.

Hall, R. (1992), The Strategic Analysis of Intangible Resources, Strategic Management Journal, volume 13, pp.135-144.

Hall, R. (1993), A Framework Linking Intangible Resources and Capabilities To Sustainable Competitive Advantage, Strategic Management Journal, volume 14, pp.607-618.

Halpern, N. and Graham, A. (2013), Airport Marketing, Routledge, Abingdon.

Hashim, F. (2014), Lion Group to Develop Jakarta's Halim Perdanakusuma Airport, Flightglonal, Subscription Only.

Havel, B. F. (2009), Beyond Open Skies: A New Regime for International Aviation, Wolters Kluwer, Biggleswade.

Henkel, M., Bider, I., Perjons, E. (2014), Capability-Based Business Model Transformation, Advanced Information Systems Engineering, volume 178, pp.88-99.

Henry, A., 2008. Understanding Strategic Management, Oxford University Press, Oxford. 
Hitt, M. A., Bierman, L., Shimizu, K., and Kochhar, R. (2001), Direct and Moderating Effects of Human Capital on Strategy and Performance in Professional Service Firms: A Resource-Based Perspective, Academic of Management Journal, volume 44, pp.1338.

Hitt, M. A., Ireland, D. R., Hoskisson, R. (2014), Strategic Management: Concepts:

Competitiveness and Globalization, $11^{\text {th }}$ edition, Cengage Learning, Stamford, USA.

Hofer, C. W. and Schendel, D. (1978), Strategy formulation: Analytical concepts, West Publishing, St. Paul, USA.

Holloway, S. (2008), Straight and Level: Practical Airline Economics, third edition, Ashgate, Aldershot.

Hoskisson, R. E., Hitt, M. A., Wan, W. P, and Yiu, D. (1999), Theory and research in strategic management: Swings of a pendulum, volume 25, pp. 417-456.

Hunt, S. D. and Moran, R. M. (1995), The Comparative Advantage Theory of Competition, Journal of Marketing, volume 59, pp.1-15.

Hutchinson, F. (2013), Southeast Asia's Largest Economy Needs Vast Improvements in Infrastructure, Perspective, volume 23.

IATA (2014), New IATA Passenger Forecast Reveals Fast-Growing Markets of the Future, available at http://www.iata.org/pressroom/pr/Pages/2014-10-16-01.aspx - accessed $22^{\text {nd }}$ January, 2015

Itami, H. and Roehl, T. W. (1987), Mobilising Invisible Assets, Harvard University Press, Harvard University Press, Cambridge, USA.

Kay, D. F., Toh, R.S and Raven, P. (2012), Auction Sales of Hotel Rooms and Airline Seats, Tourism Analysis, volume 17, pp.239-243, http://dx.doi.org/10.3727/108354212X13388995268020

Low, J. M. W. and Lee, B. K. (2014), Effects of Internal Resources on Airline Competitiveness, Journal of Air Transport Management, volume 36, pp.23-32, doi:10.1016/j.jairtraman.2013.12.001

Manila Bulletin (2014), Philippines to build third runway at Manila's congested airport, available at http://www.mb.com.ph/philippines-to-build-third-runway-at-manilascongested-airport/ - accessed $22^{\text {nd }}$ January, 2015

Michalisin, M. D., Smith, R. D., and Kline, D. M. (1997), In Search of Strategic Assets, International Journal of Organisational Analysis, volume 5, pp.360-387.

Oliver, C. (1997), Sustainable competitive advantage: Combining institutional and resource-based views, Strategic Management Journal, volume 18, pp.697-713. 
Merkert, R. and Pearson, J. (2014), A Non-parametric Efficiency Measure Incorporating Perceived Airline Service Levels and Profitability, Journal of Transport Economics and Policy, awaiting publication and presently available online.

Narangajavana, Y., Garrigos-Simon, F. J., Sanchez, J. G., Forgas-Coll, S. (2014), Prices, Prices and Prices: A Study in the Airline Sector, Tourism Management, volume 41, pp.28-42, doi:10.1016/j.tourman.2013.08.008.

Pearson, J. and Merkert, R. (2014), Airlines-within-airlines: A Business Model Moving East, Journal of Air Transport Management, volume 38, pp.21-26, DOI: 10.1016/j.jairtraman.2013.12.014

Peng, M. (2008), Global Strategy, second edition, Cengage Learning, Mason, USA.

Pilarski, A. M. (2007), Why Can’t We Make Money In Aviation?, Ashgate, Aldershot.

Port Calls Office (2008), Manila, HK scramble to ease demand-driven air traffic congestion, available at: http://www.portcalls.com/manila-hk-scramble-to-ease-demand-driven-airtraffic-congestion/\# - accessed 8th June 2015.

Porter, M. E. (1980), Competitive Strategy, Free Press, New York.

Powell, T. C. and Dent-Micallef, A. (1997), Information Technology as Competitive Advantage: The Role of Human, Business, and Technology Resources, Strategic Management Journal, volume 18, pp.375-405.

Prahalad, C. K. and Hamel, G. (1990), The Core Competence of the Corporation, in Zack, M. H. (1999) (ed.), Knowledge and Strategy, Butterworth-Heinemann, USA.

Robinson, S. (2008), Understanding the Resource-Based View: Implications of Methodological Choice and a New Creative Context, PhD thesis, Queensland University of Technology.

Shaw, S. (2007), Airline Marketing and Management, sixth edition, Ashgate, Farnham.

Tan, A. K. J. (2014), The ASEAN Single Aviation Market: Liberalizing the Airline Industry, ERIA Policy Brief, June.

Tyler, B. B. (2001), The Complementarity of Cooperative and Technological Competences:

A Resource-Based Perspective, Journal of Engineering and Technology Management, volume 18, pp.1-27.

Vomberg, A., Homburg, C., Bornemann, T. (2014), Talented People and Strong Brands: The Contribution of Human Capital and Brand Equity to Firm Value, Strategic Management Journal, DOI: 10.1002/smj.2328.

Wharton School (1997), Wharton on Dynamic Competitive Strategy. Wiley, Chichester.

Wit, B.D. and Meyer, R. (1999), Strategy Synthesis: Resolving Strategy Paradoxes to Create Competitive Advantage. International Thomson Business, London. 